Bird Conservation International (2002) 12:151-167. (C) BirdLife International 2002

DOI: $10.1017 /$ S0959270902002095 Printed in the United Kingdom

\title{
Factors affecting the distribution of landbirds on the Falkland Islands
}

\author{
JAMES R. HALL, ROBIN W. WOODS, M. de L. BROOKE and \\ GEOFF M. HILTON
}

\begin{abstract}
Summary
A high proportion of island birds are threatened with extinction as a result of their vulnerability to introduced predators, habitat destruction, and fragmentation/isolation effects. In order to conserve island species effectively, it is necessary to disentangle these effects on distribution and abundance. We attempt to do this for the nine native passerines in the Falkland (Malvinas) Islands, using a database of presence/absence on 59 offshore islands in the archipelago, linked to data for each island on mammal presence, habitat modification, and isolation. Falklands native passerines are of considerable conservation importance, comprising one endemic globally threatened species, several endemic subspecies, and several restricted range species. Presence of rats on islands was by far the most important predictor of passerine presence, overriding the effect of habitat modifications. The globally threatened endemic Cobb's Wren Troglodytes cobbi was absent from all islands containing rats. Some species were more likely, and others less likely to occur on islands where tussac Poa flabellata grassland had been destroyed by grazing. The former species were primarily those adapted to dwarf-heath vegetation, and/or that thrive around human settlements. Island size and isolation were important predictors of occurrence for several bird species. The analyses show that, if vegetation restoration in the Falklands is to meet conservation aims, then it should be accompanied by introduced mammal control. Secondly, they indicate that biogeographical effects on bird distribution among islands in the Falklands are important, and need to be considered when assessing the conservation status of species, and when considering conservation action.
\end{abstract}

\section{Introduction}

The distribution of birds on small islands has proved a fruitful source of information about biogeographical processes, such as the persistence of small populations (Pimm et al. 1988), the possibility that observed assemblages may be structured by competition (Diamond 1975, Grant 1986), and rates of molecular evolutionary change (Fleischer et al. 1998). In a conservation context, the pattern of distribution of species across islands can also yield information about the environmental factors affecting them, and this can be used to identify conservation actions for threatened species.

Island bird species have suffered the greatest rates of anthropogenic extinction in recent years, and constitute a disproportionately large number of currently threatened species (BirdLife International 2000). Their typically small populations and range sizes make them particularly vulnerable to habitat destruction, and they are frequently sensitive to introduced predators (Atkinson 1989). Fur- 
thermore, their restriction to one or more small, discrete sites makes them inherently vulnerable to catastrophic and stochastic events that can eliminate populations (Moors 1985, Whittaker 1998). Disentangling these combined threats, and assessing which are the most important, can be difficult. However, the Falkland (Malvinas) Islands present an unusual opportunity to do so, because they comprise an archipelago of islands that differ in size, isolation, habitat modification, and presence of introduced predators.

Human colonization of the Falklands has led to several drastic environmental changes that have had massive impacts on the distribution and numbers of this insular fauna. First, grazing by domestic stock dramatically reduced the area of natural vegetation, in particular of coastal tussac Poa flabellata grassland, this habitat having been reduced in extent by c. $80 \%$ since human settlement (Strange et al. 1988). Second, alien mammalian predators - cats Felis catus, rats Rattus rattus, $R$. norvegicus, house mice Mus musculus and Patagonian foxes Dusicyon griseus - have been introduced. All except the last species have spread widely over most of the islands. However, prior to human introductions from the mideighteenth century, there was one terrestrial mammal species, the warrah Dusicyon australis, a close relative of the Patagonian fox, but it was exterminated by 1876 (Woods 1988). There is no evidence that it occurred on any of the islands except the main landmasses of East and West Falkland. As a consequence of the introductions, areas with native vegetation communities, and mammal-free areas, are now generally small and widely scattered in the Falklands, mostly on small offshore islands. A third potentially important environmental change therefore is the fragmentation and isolation of native habitat. This biogeographical effect may lead to increased extinction rates and reduced recolonization of islands of suitable habitat (MacArthur and Wilson 1967, Hanski 1999).

Previous work in the Falklands, notably the Breeding Birds Survey (Woods and Woods 1997), has shown that, at a broad scale, native landbirds have indeed changed their distributions greatly, and it has generally been inferred that some combination of habitat loss and introduced predators has caused these changes (e.g. Woods 1988, Strange 1992, Stattersfield et al. 1998). Some species remain widespread throughout the Falklands, while others are more or less confined to offshore islands (Table 1). Successful conservation depends on disentangling and identifying the key environmental changes that have determined the distribution of each species. Here we report on an analysis of the relationship between environmental factors and the presence of nine native passerine species across islands in the Falklands.

\section{Study area and methods}

The Falkland Islands lie east of Argentina between $51^{\circ} \mathrm{S}$ and $53^{\circ} \mathrm{S}$ in the South Atlantic Ocean (Figure 1), and have a natural vegetation of steppe-grassland, dwarf-heath, and tussac grassland. They have a distinctive landbird passerine fauna, with substantial levels of endemism. There are three restricted range species of the Southern Patagonia Endemic Bird Area (Stattersfield et al. 1998) one of which, Cobb's Wren Troglodytes cobbi, is a globally threatened endemic to the islands (BirdLife International 2000). Five of the remaining landbird species occur 
Table 1. Species included in this study, with their status, distribution and known habitat preferences

\begin{tabular}{|c|c|c|}
\hline Species & Status & Distribution within the Falklands ${ }^{a}$ \\
\hline $\begin{array}{l}\text { Blackish Cinclodes (Tussacbird) } \\
\text { Cinclodes antarcticus }\end{array}$ & $\begin{array}{l}\text { Endemic subspecies; } \\
\text { restricted range species }\end{array}$ & $\begin{array}{l}\text { Entirely coastal. Almost entirely } \\
\text { on offshore islands }\end{array}$ \\
\hline $\begin{array}{l}\text { Dark-faced Ground-tyrant } \\
\text { Muscisaxicola macloviana macloviana }\end{array}$ & Endemic subspecies & $\begin{array}{l}\text { Widespread, including inland } \\
\text { areas and mainland islands }\end{array}$ \\
\hline $\begin{array}{l}\text { Correndera (Falkland) Pipit } \\
\text { Anthus correndera grayi }\end{array}$ & Endemic subspecies & $\begin{array}{l}\text { Widespread, including inland } \\
\text { areas and mainland islands }\end{array}$ \\
\hline $\begin{array}{l}\text { Grass (Falkland) Wren } \\
\text { Cistothorus platensis falklandicus }\end{array}$ & Endemic subspecies & $\begin{array}{l}\text { Widespread but patchy } \\
\text { distribution, including inland } \\
\text { areas and mainland islands }\end{array}$ \\
\hline $\begin{array}{l}\text { Cobb's Wren } \\
\text { Troglodytes cobbi }\end{array}$ & $\begin{array}{l}\text { Endemic species, globally } \\
\text { vulnerable }^{\mathrm{b}}\end{array}$ & $\begin{array}{l}\text { Small number of offshore islands } \\
\text { only }\end{array}$ \\
\hline $\begin{array}{l}\text { Austral (Falkland) Thrush } \\
\text { Turdus falcklandii falcklandii }\end{array}$ & Endemic subspecies & $\begin{array}{l}\text { Widespread, including inland } \\
\text { areas and mainland islands }\end{array}$ \\
\hline $\begin{array}{l}\text { Canary-winged Finch } \\
\text { Melanodera melanodera melanodera }\end{array}$ & $\begin{array}{l}\text { Endemic subspecies; } \\
\text { restricted range species }\end{array}$ & $\begin{array}{l}\text { Widespread, including inland } \\
\text { areas and mainland islands }\end{array}$ \\
\hline $\begin{array}{l}\text { Long-tailed Meadowlark } \\
\text { Sturnella loyca falklandicus }\end{array}$ & Endemic subspecies & $\begin{array}{l}\text { Widespread, including inland } \\
\text { areas and mainland islands }\end{array}$ \\
\hline $\begin{array}{l}\text { Black-chinned Siskin } \\
\text { Carduelis barbata }\end{array}$ & $\begin{array}{l}\text { Possibly endemic } \\
\text { subspecies }\end{array}$ & $\begin{array}{l}\text { Entirely coastal, on mainland } \\
\text { islands and offshore islands, often } \\
\text { associated with settlements }\end{array}$ \\
\hline
\end{tabular}

a'Data summarized from Woods and Woods (1997). 'Mainland islands' refers to East and West Falkland. 'Offshore islands' refers to all the other, smaller islands in the archipelago.

bee BirdLife International (2000).

'Restricted to Endemic Bird Area o62, Southern Patagonia (Stattersfield et al. 1998).

${ }^{\mathrm{d}}$ See Woods and Woods (1997).

as endemic subspecies in the Falklands, while the remaining species may also occur as a unique subspecies (Table 1 ).

Monthly mean temperatures in the Falkland Islands vary from $2^{\circ} \mathrm{C}$ in July to $9^{\circ} \mathrm{C}$ in January. Persistent strong winds mean that there are few species of flying insect in the archipelago. There are no native trees, but many non-native species have been planted. Most of the vegetation is dwarf-heath, dominated by whitegrass Cortaderia pilosa, diddle-dee Empetrum rubrum and low cushion-forming plants, with tussac originally forming a fringe around islands. However, almost the entire tussac fringe on the main islands of East and West Falkland has been lost due to overgrazing by introduced sheep and cattle, and also through fires (Woods 1988, Strange 1992, Woods and Woods 1997, Stattersfield et al. 1998). Tussac is now largely limited to some of the $c .750$ smaller islands (Woods 1986).

During a census of Striated Caracara Phalcoboenus australis in 1997/8, RWW developed a database of environmental factors and bird presence at 59 offshore islands around the Falklands. For each island, the following variables were recorded:

1. Presence/absence of the nine native passerine species that breed regularly in the Falklands (Woods and Woods 1997).

2. Presence/absence of cats, rats, mice and Patagonian foxes.

3. Presence/absence of grazing by sheep and cattle currently and in the past (two separate binary variables). Grazing includes all intensities of grazing, 


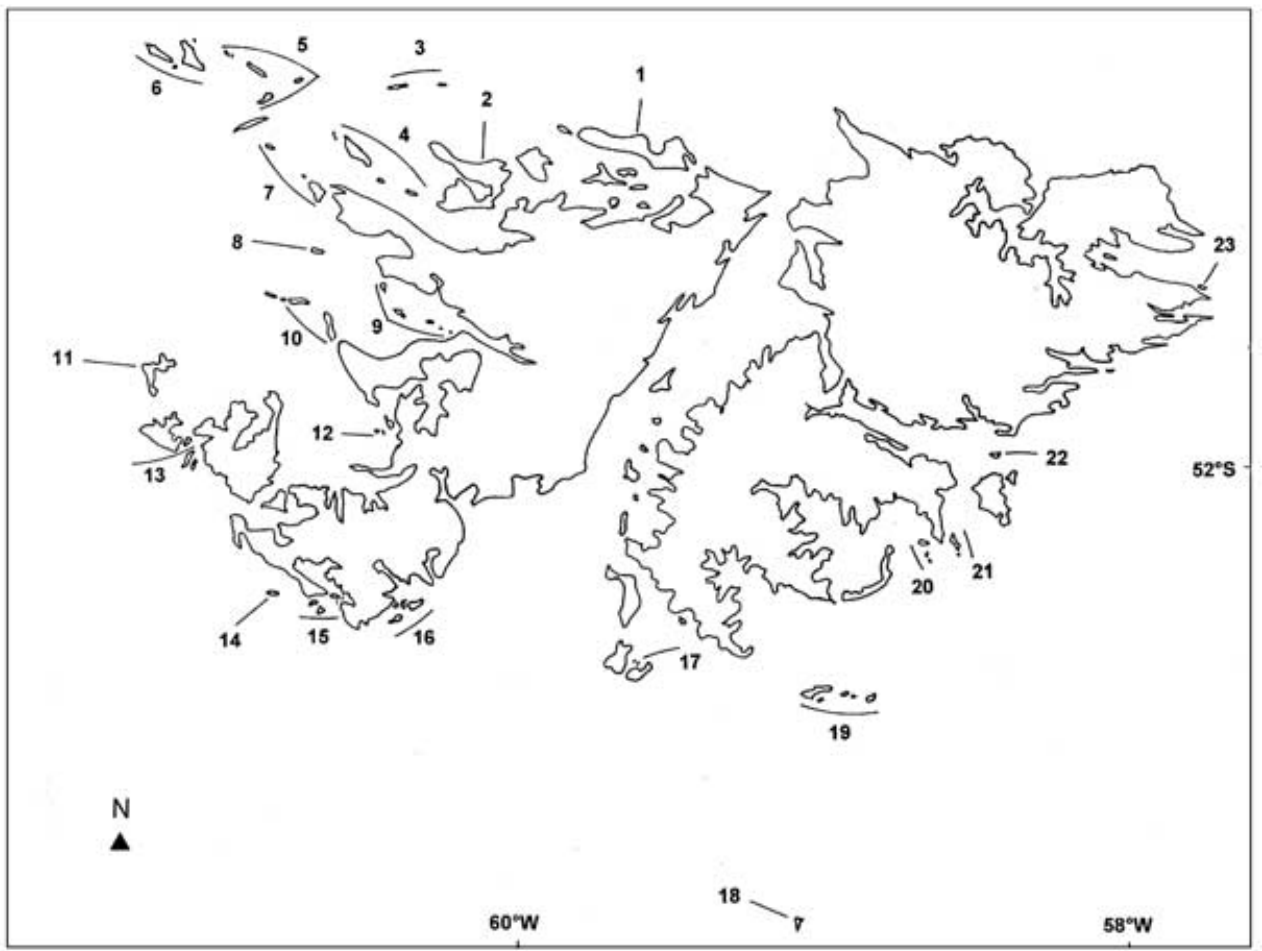

Figure 1. Map of the Falkland Islands, showing the study islands. Key to numbered islands and island groups (within groups, islands are listed from east to west): 1 , Pebble; 2, Saunders; 3, Wreck, Sedge; 4, Dunbar, Low, Carcass, The Twins (S and N); 5, North Fur, Elephant Jason, Flat Jason, The Fridays (2); 6, Clarke's Islet, Grand Jason, Steeple Islet, Steeple Jason; 7, West Point, Gibraltar Rock, South Fur; 8, Split; 9, Green, Gid's, Middle, Hummock, Rabbit (King George Bay); 10, First and Second Passage; 11, New; 12, Double and Outer; 13, Governor, Beaver; 14, Bird; 15, Ten Shilling Bay (E and W), Cross, and Islands Two, Four Five and Six to the east; 16, Big Arch, Sand Bay (west of Big Arch), Natural Arch, Tussac; 17, Emily and Tiny (east of George); 18, Beauchêne; 19, Sea Lion Easterly, Whisky, Brandy, Rum, Sea Lion; 20, Outer Triste (S and N), Triste; 21, Motley, The Mot; 22, Middle (Choiseul Sound); 23, Kidney.

and all species of grazing mammals. Grazing began during the nineteenth century, but on some islands ceased between seven and 30 years before present. These islands are recorded as 'grazed in the past' (as are all currently grazed islands). The impact of grazing has varied, according to its intensity. In some areas, grazing has destroyed tussac, leaving bare peat, which subsequently erodes to mineral soil and rock; at other sites, a short sward of mainly non-native herbaceous vegetation has developed. In some areas, there is a mosaic of tussac (which has been allowed to regenerate to provide shelter), and short grazed vegetation.

4. Tussac quality, graded on a five point system A-E: A, complete tussac cover; B, partial tussac cover; C, substantial erosion of former tussac fringe; D, remnant tussac on points or in paddocks; E, no tussac. 
In addition, as measures of isolation/fragmentation, the distance to the nearest known population on a surveyed island of each bird species $(\mathrm{m})$, and the distance to the nearest of the mainland islands (East and West Falkland, m) were measured for each island using a Directorate of Overseas Surveys 1: 643,000 map. The land area of each island was calculated from 1:50,000 maps.

Where an island had missing values for a variable, the island was excluded from regressions involving that variable. Three of the predators (cats, mice and foxes) were subsequently excluded from the analyses, either because there were too few islands where they were present (cats and foxes: each present on two islands) or because of uncertainty about presence on the majority of islands (mice: 34 missing or uncertain entries). For each bird, the dependent variable was presence/absence. The independent variables (island size, distance to the main islands, distance from nearest known conspecific population, rat presence, past grazing, present grazing and tussac quality) were modelled using binary logistic regression and reverse elimination. The least significant factor is removed from the model and the process repeated until all of the remaining factors have a significant effect when removed, using a $P$ value of 0.05. For Dark-faced Ground-tyrant Muscisaxicola macloviana macloviana, backwards elimination produced a very poorly fitting model, so forward addition of variables was used. At each step, the significant variable $(P>0.05)$ that caused the biggest reduction in overall model deviance was added to the model. A positive coefficient signifies a positive association with bird presence.

\section{Results}

All of the bird species except Correndera Pipit Anthus correndera grayi were relatively widespread among the sampled islands, but were absent from an appreciable proportion (27-53\%) of them (Appendix 1). Correndera Pipit was rare, occurring on only $16 \%$ of islands.

Rats were the most important predictor of distribution for every bird species. For seven species, rat presence was negatively associated with bird species presence. Cobb's Wren was absent from every island on which rats were present, and present on every island on which rats were absent. Blackish Cinclodes Cinclodes antarcticus was present on three islands on which rats were present, and on all islands on which rats were absent. However, for Grass Wren Cistothorus platensis falklandicus and Dark-faced Ground-tyrant, there was a positive association with rat presence (Table 2 ).

Grazing, both now and in the past, was a significant predictor of bird presence in a number of cases. Black-chinned Siskin Carduelis barbata was more likely to be present in areas where there was both past and present grazing. Austral Thrush Turdus falcklandii falcklandii presence was positively associated with past grazing, but there was no relationship with current grazing. For Canary-winged Finch Melanodera melanodera melanodera and Long-tailed Meadowlark Sturnella loyca falklandicus, the results were contradictory: the former species showed a positive association with current grazing, but a negative association with past grazing; the latter species's presence was negatively associated with current grazing but positively with past grazing (Table 2 ). 
Table 2. Environmental factors significantly associated with the presence/absence of passerine bird species on 57 islands in the Falkland Islands archipelago

\begin{tabular}{|c|c|c|c|}
\hline Bird species & $\begin{array}{l}\text { No. occupied } \\
\text { islands / islands } \\
\text { surveyed }\end{array}$ & $\begin{array}{l}\text { Significant factors } \\
\text { (direction of relationship) }\end{array}$ & $\begin{array}{l}P \\
\text { (Deviance } / d f \text { ) }\end{array}$ \\
\hline Blackish Cinclodes & $40 / 59$ & Rats (-) & $\begin{array}{l}<0.005 \\
(17.5)\end{array}$ \\
\hline \multirow[t]{3}{*}{ Dark-faced Ground-tyrant } & \multirow{3}{*}{$34 / 57$} & Rats (+) & $<0.005$ \\
\hline & & Island area $(+)$ & $<0.005$ \\
\hline & & Distance to nearest population $(+)$ & $\begin{array}{l}<0.005 \\
(3.88)\end{array}$ \\
\hline \multirow[t]{4}{*}{ Correndera Pipit } & \multirow[t]{4}{*}{$9 / 57$} & Rats (-) & $<0.005$ \\
\hline & & Tussac quality $(+)$ & $<0.005$ \\
\hline & & Distance to main islands (-) & $<0.005$ \\
\hline & & Distance to nearest population $(-)$ & $\begin{array}{l}<0.005 \\
(0.00)\end{array}$ \\
\hline \multirow[t]{4}{*}{ Grass Wren } & \multirow[t]{4}{*}{$43 / 59$} & Rats (+) & $<0.005$ \\
\hline & & Island area $(+)$ & $<0.005$ \\
\hline & & Distance to main islands (-) & $<0.005$ \\
\hline & & Distance to nearest population (-) & $\begin{array}{l}<0.029 \\
(1.87)\end{array}$ \\
\hline Cobb's Wren & $31 / 59$ & Rats (-) & $\begin{array}{l}<0.005 \\
(0.00)\end{array}$ \\
\hline \multirow[t]{4}{*}{ Austral Thrush } & \multirow[t]{4}{*}{$39 / 57$} & Rats (-) & $<0.005$ \\
\hline & & Island area (+) & $<0.005$ \\
\hline & & Grazed in past $(+)$ & $<0.005$ \\
\hline & & Distance to main islands (-) & $\begin{array}{l}<0.038 \\
(5.28)\end{array}$ \\
\hline \multirow[t]{3}{*}{ Canary-winged Finch } & \multirow[t]{3}{*}{$37 / 57$} & Rats (-) & $<0.005$ \\
\hline & & Grazed now $(+)$ & $<0.005$ \\
\hline & & Grazed in past $(-)$ & $\begin{array}{l}<0.045 \\
(7.09)\end{array}$ \\
\hline \multirow[t]{5}{*}{ Long-tailed Meadowlark } & \multirow{5}{*}{$27 / 57$} & Rats (-) & $<0.005$ \\
\hline & & Tussac quality (-) & $<0.0001$ \\
\hline & & Distance to main islands (-) & $<0.005$ \\
\hline & & Grazed now (-) & $<0.005$ \\
\hline & & Grazed in past $(+)$ & $\begin{array}{l}<0.005 \\
(1.52)\end{array}$ \\
\hline \multirow[t]{4}{*}{ Black-chinned Siskin } & \multirow[t]{4}{*}{$32 / 57$} & Rats (-) & $<0.005$ \\
\hline & & Grazed now $(+)$ & $<0.005$ \\
\hline & & Grazed in past $(+)$ & $<0.005$ \\
\hline & & Distance to main islands (-) & $\begin{array}{l}<0.052 \\
(10.1)\end{array}$ \\
\hline
\end{tabular}

Significant predictors listed in order of significance in the model. The direction of the relationship of each factor is shown by a plus (positive) or minus (negative) sign. Deviance/df is a measure of goodness of fit for the overall model (values approaching zero having a good fit).

The quality of tussac on each island was negatively associated with the presence of Long-tailed Meadowlark (the species was more likely to be present where tussac was of poor quality or absent). The presence of Correndera Pipit was positively associated with tussac quality, though we suspect this relationship is not causal (see Discussion) (Table 2).

Among biogeographical factors, the presence of Grass Wren and Correndera 
Table 3. Comparison of adult body size, clutch size and number of broods per season for nine Falkland Island bird species positively or negatively associated with the presence of rats

\begin{tabular}{llll}
\hline & $\begin{array}{l}\text { Mean adult body } \\
\text { size, length cm, (SD) }\end{array}$ & $\begin{array}{l}\text { Mean clutch } \\
\text { size (SD) }\end{array}$ & $\begin{array}{l}\text { Mean number of } \\
\text { broods per season (SD) }\end{array}$ \\
\hline $\begin{array}{l}\text { Species negatively associated with } \\
\text { rat presence }(n=7)\end{array}$ & $17.8(5.5)$ & $3.1(0.7)$ & $2.3(0.5)$ \\
$\begin{array}{l}\text { Species positively associated with } \\
\text { rat presence }(n=2)\end{array}$ & $13.8(3.2)$ & $4.3(2.5)$ & $1.5(0.5)$ \\
\hline
\end{tabular}

Data from Woods (1988) and Woods and Woods (1997).

Pipit was negatively related to distance to the nearest conspecific population thus these species were more likely to be present where there were other populations nearby. However, for Dark-faced Ground-tyrant, the reverse relationship was significant: they were more likely to be present at sites remote from other occupied sites. Distance to the closer of the two main Falkland islands was negatively associated with the presence of Grass Wren, Austral Thrush, Correndera Pipit, Long-tailed Meadowlark, and Black-chinned Siskin; thus these species were less likely to be present at sites remote from the main islands. Grass Wren, Dark-faced Ground-tyrant and Austral Thrush were more likely to be present on larger islands (Table 2).

Differences in adult body size, clutch size and number of clutches per season were compared for those species positively associated and negatively associated with rats (Table 3). There was no tendency for those negatively affected to be smaller or to have significantly smaller or fewer clutches.

\section{Discussion}

Tests of the associations between bird presence and environmental factors allow hypotheses to be developed and, potentially, tested experimentally. In these analyses, there are strong correlations between some of the predictor variables, which means that the results must be treated with some caution. For instance, small, remote, uninhabited islands are likely to be both ungrazed and unpopulated by introduced predators. Similarly, variables such as rat presence may act as proxies for a number of other important factors associated with human influence. However, these analyses show some intriguing patterns. We will attempt to explain why the bird species responded differently to the various factors, and then consider the management and conservation implications of the findings.

In this study, the presence of rats was by far the most important predictor of bird species presence - generally with a strong negative association. This suggests that the impact of rat presence overrides habitat or biogeographical factors, and is a sufficient condition for absence of some bird species from islands in the Falklands. Norway rats probably arrived in the Falkland Islands between 1725 and 1833 (Atkinson 1985), but the dates of arrival on each offshore island are not known. Black rat is also present, but its history on the islands is poorly recorded (Woods and Woods 1997). The very strong negative association between rats and birds (particularly in the case of Cobb's Wren, where it explains all the variance in the regression) may mask important effects of habitat or biogeographical fac- 
tors that are correlated with rat presence. For instance, Woods (1993) showed that, in the absence of rats, Cobb's Wren densities varied substantially according to tussac quality. Thus, rat absence may not be a sufficient condition to allow populations of all species to persist.

Island bird species most at risk from rat predation are smaller species and those without prior exposure to mammalian predators (Moors 1985). Falkland landbirds have evolved in isolation from mainland counterparts, hence they are almost all endemic subspecies or species. However, the Falklands held a mammalian predator - the warrah - prior to anthropogenic introductions in the eighteenth century. It is unclear whether this species was a natural colonist, or was introduced by aboriginal South Americans, nor how long it had been on the islands. It is also not clear what impact warrahs might have had on native passerines. Reports suggest that warrahs may typically have preyed on larger birds such as geese and penguins, but predation on smaller birds may have escaped notice. Possibly its historical presence resulted in the maintenance of antipredator behaviour among Falklands birds that would have been inherited from ancestral populations in mainland South America. Alternatively, it may have had a significant effect on passerine distribution, which was merely continued by later anthropogenic mammal introductions. In any event, prior exposure to mammalian predation does not always prevent rats having a severe impact on an avifauna (Atkinson 1985). The impact of Norway rat predation is generally most severe for ground-nesting species (Atkinson 1985). Because of the vegetation types prevalent on the Falklands, almost all passerine birds nest and forage at or near ground level. Cobb's Wren forages for invertebrate prey beneath boulders on beaches, which may make the adults vulnerable to rat predation, even when not on the nest. In general, small bird species that have long incubation periods, and make limited numbers of nesting attempts are most heavily impacted by rats of all types. However, there was no evidence among our species that size, clutch size or number of nesting attempts predicted sensitivity to rat presence. While the effects of other predators were not considered by this study, it is extremely likely that mice, cats and foxes have had a negative impact on the avifauna of islands in the Falklands (Johnson and Stattersfield 1990).

Why do Dark-faced Ground-tyrant and Grass Wren show a positive association with rat presence? Since we assume that rats themselves are not beneficial, we surmise that some further effect is involved. Pettingill (1974) observed that Dark-faced Ground-tyrants were most common around settlements, so it is possible that this reflects a positive association among both rats and tyrants to human occupation. However, this link does not seem to explain the association of Grass Wrens with rats. Dark-faced Ground-tyrants feed predominantly on flying insects caught on the wing and Grass Wrens feed mostly above ground level, at least in tussac (Woods and Woods 1997). These feeding behaviours may reduce the vulnerability of adults to rat predation.

Tussac is thought to be an extremely important habitat for Falkland birds (Cawkell and Hamilton 1961, Woods 1970, 1988, 1993, Woods and Woods 1997) so it is surprising that no species were clearly associated with an absence of grazing, and only one species - Correndera Pipit - was associated with good quality tussac. The preferred habitats of this species are white-grass dwarf-heath, and sand beaches (Woods and Woods 1997), and it does not occur in stands of 
dense tussac; the association is possibly an artefact caused by a small number of positive records for this species, or an unknown confounding variable. In fact our analysis, by considering only presence/absence on islands, rather than abundance, probably underestimates the importance of tussac. Woods (1984) showed that, independent of predator presence, Cobb's Wren, Grass Wren and Austral Thrush reach higher densities in good quality mature tussac than in areas with poor quality tussac and grazed patches. Blackish Cinclodes apparently reaches highest densities in a mosaic of mature tussac and open grazed areas (Woods 1984), and this may also be true of Austral Thrush. Furthermore, dense growth of tussac benefits other species, notably burrow-nesting Procellariiform seabirds, of which the Falkland Islands hold globally important populations (Croxall et al. 1984).

Black-chinned Siskin was positively associated with past and present grazing, while Long-tailed Meadowlark was associated with absent/poor quality tussac. These species, along with Dark-faced Ground-tyrant and Canary-winged Finch, primarily feed in open areas, and use the widespread dwarf-heath habitat that covers inland areas in the Falklands. Anthropogenic replacement of tussacfringed coastline with grazed grassland may thus have created new shortvegetation habitat for them (Pettingill 1974, Woods and Woods 1997). In addition, creation of perches such as fence posts in grazed areas may have benefited some species, notably Dark-faced Ground-tyrant, Long-tailed Meadowlark and Blackchinned Siskin. The latter is known to exploit introduced food plants (e.g. Taraxacum spp. and Rumex acetosella in grazed areas), and potentially benefits from the presence of taller non-native shrubs and trees as nesting sites in farmed areas (Woods and Woods 1997, RWW pers. obs.).

Theory predicts that small, isolated patches of habitat are less likely to support populations of a species, because they have a higher rate of extinction and a lower rate of recolonization (Hanski 1999). Hence we would predict that species are less likely to be present on small islands, and islands that are remote from other populations. Our additional variable - 'distance from the mainland' (East or West Falkland) - may be relevant for species which are still widespread on the main islands, since the mainland could act as a source for colonization. There was some evidence for biogeographical effects on bird presence. Three species (Grass Wren, Dark-faced Ground-tyrant and Austral Thrush) were more likely to be present on larger islands. Furthermore, distance to the nearest conspecific population was negatively associated with the presence of Grass Wren and Correndera Pipit. For five species, increasing distance from the main islands reduced the likelihood that they would be present. Four of these, Grass Wren, Austral Thrush, Correndera Pipit and Long-tailed Meadowlark, are widespread on the mainland islands. Black-chinned Siskin has a predominantly coastal/island distribution, probably related to the distribution of settlements where trees and shrubs have been planted. There was no evidence that Cobb's Wren and Blackish Cinclodes, which are almost confined to offshore islands, are affected by biogeographical effects. Curiously, Dark-faced Ground-tyrant presence is more likely with increasing distance from conspecific populations. This result is difficult to interpret. It could arise as an artefact if the species were absent on a particular group of islands for ecological reasons, making the species appear to be overdispersed. 
The approach used here has proved valuable in revealing associations between bird presence and environmental variables. Some counter-intuitive relationships (such as those between rat presence and bird presence, and between bird presence and distance from conspecifics) were found. These are likely to be artefacts resulting from the superficial nature of the data, and suggest limits to the inferences that can be made from these analyses. In addition, developing a Minimum Adequate Model for each species using multiple independent variables means that there is a relatively high probability of statistically significant associations arising by chance (though note that most significant associations had $P<0.005$, Table 2).

Experimental tests of the correlations shown here would confirm causation in these relationships. It appears that rats are currently the most important influence on native passerine distribution in the Falklands; their effect on presence/ absence outweighs that of habitat quality. This is despite the fact that Falklands passerines evolved, at least on East and West Falkland, in the presence of a mammalian predator. Hence islands containing good quality, ungrazed habitat cannot reach their potential conservation value without mammal eradication or control; likewise, moves to prevent grazing and restore tussac should be accompanied by mammal eradication or control. Fortunately, a programme of rat eradication on tussac islands has recently begun in the Falklands (R. J. Ingham pers. comm.).

Importantly, we have shown for the first time that biogeographical factors help explain the observed distribution of some Falklands passerines. For some species, island size and isolation is a significant predictor of presence/absence. This implies that such factors should be a practical consideration when planning conservation measures in the archipelago. In addition, there is often a time-lag between habitat fragmentation and a decline in the number of occupied fragments - the so-called extinction debt (Tilman et al. 1994). Hence some species considered here may be expected to suffer a further net loss of island subpopulations as a result of biogeographical effects, even if there is no further spread of mammals or habitat destruction.

\section{Acknowledgements}

We thank the Falkland Islands Government for commissioning the Striated Caracara survey in 1997 and 1998, which allowed the collection of data on other birds to take place. We are very grateful to landowners and managers for allowing access to their properties, and thank Jonathan Meiburg, Michael Morrison and Ann Prior for all their efforts in the fieldwork. We are indebted to Michael and Jeanette Clarke for their skilful handling of the 70-year-old auxiliary ketch Penelope and the support given to the observers during this survey. Without their help the data on passerines, predators and tussac condition could not have been collected. Thanks also to Rhys Green (RSPB) for statistical advice. 


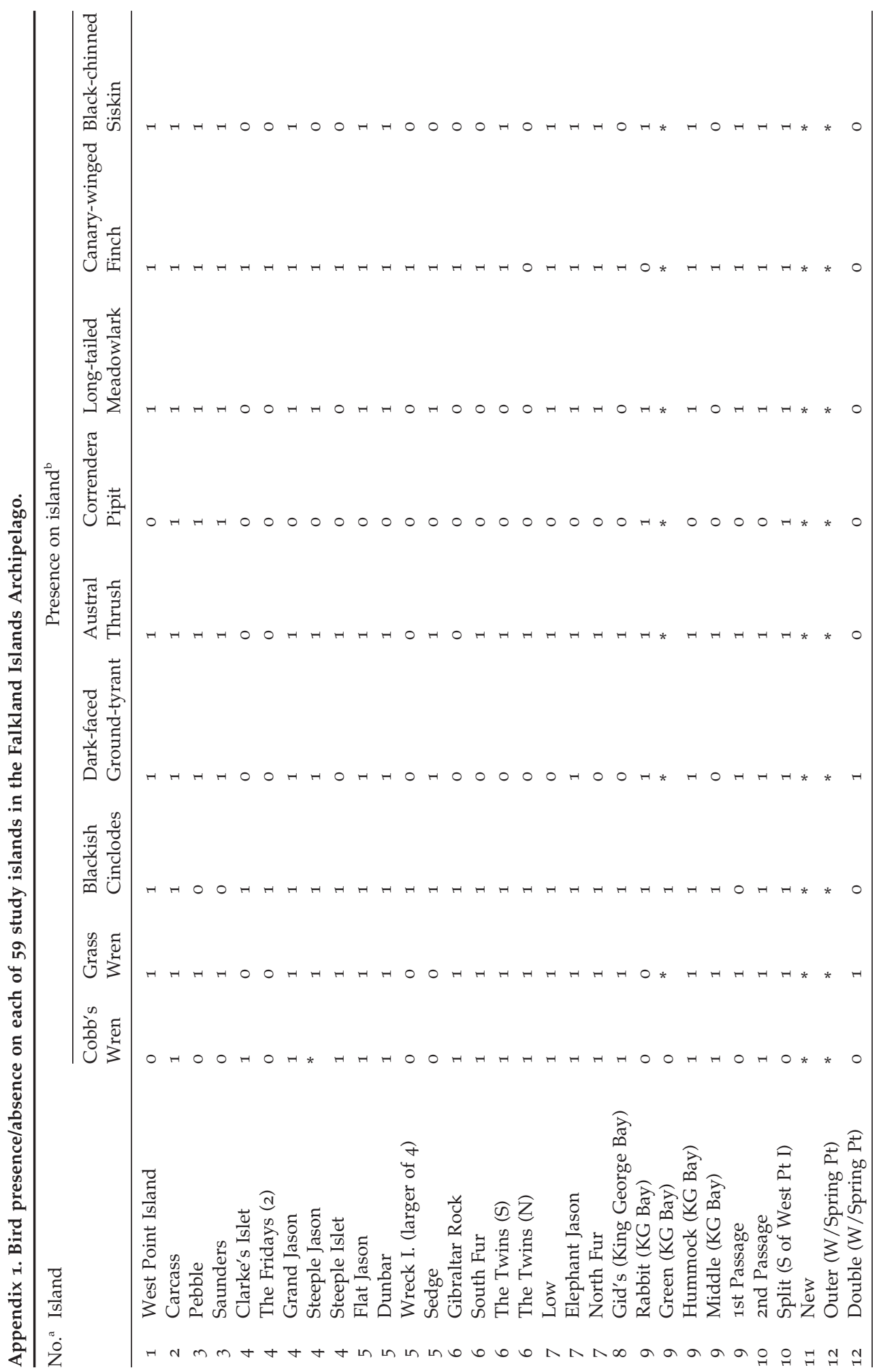


J.R. Hall et al.

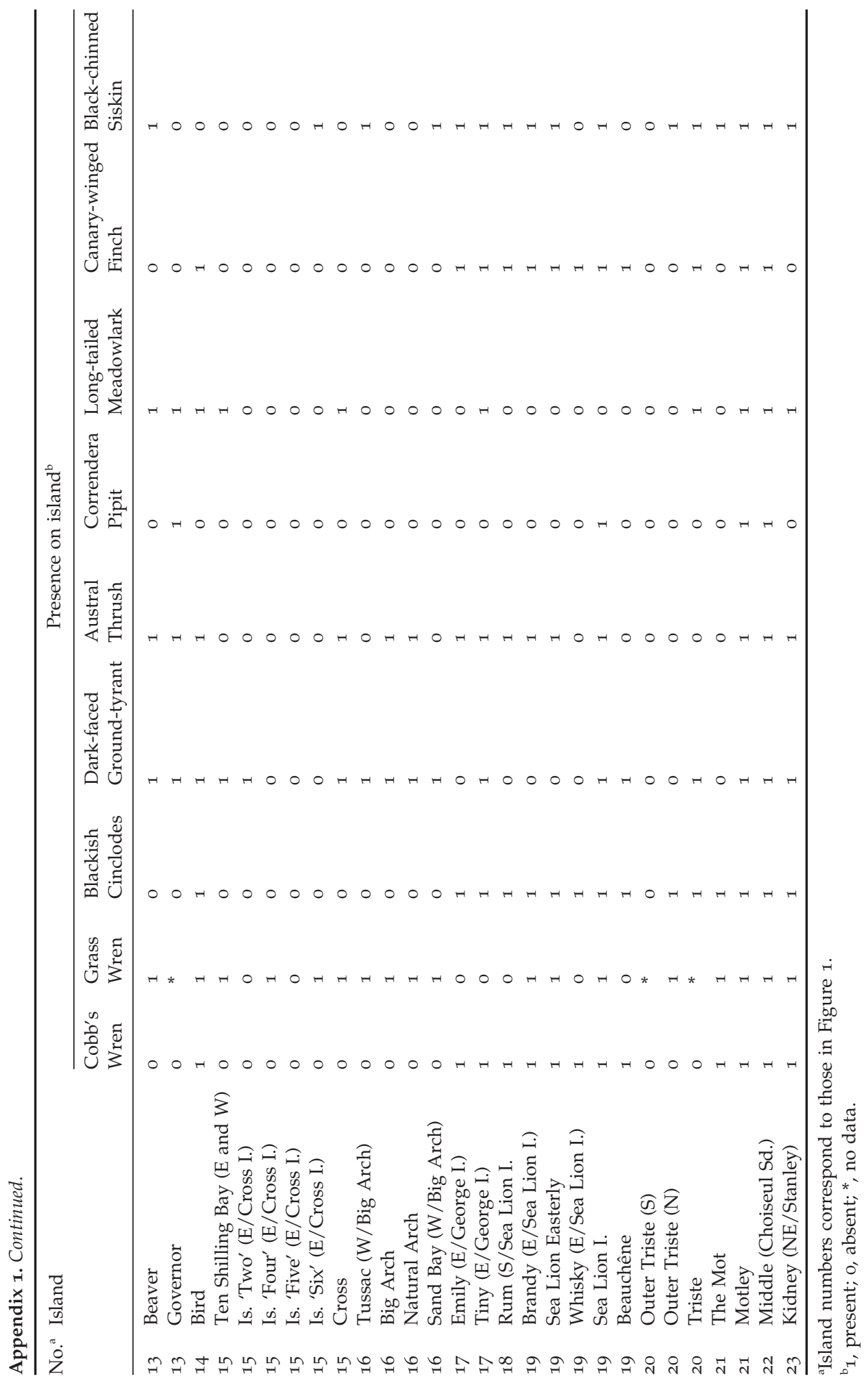


Appendix 2. Habitat and predator data for each of 59 study islands in the Falkland Islands Archipelago.

\begin{tabular}{|c|c|c|c|c|c|c|}
\hline No. ${ }^{a}$ & Island & $\begin{array}{l}\text { Area } \\
\text { (ha) }\end{array}$ & $\begin{array}{l}\text { Grazed in } \\
\text { past }^{\text {b }}\end{array}$ & $\begin{array}{l}\text { Grazed } \\
\text { now }^{\mathrm{b}}\end{array}$ & $\begin{array}{l}\text { Tussac } \\
\text { quality }\end{array}$ & Rats $^{d}$ \\
\hline 1 & West Point Island & 1,255 & 1 & 1 & $\mathrm{D}$ & 1 \\
\hline 2 & Carcass & 1,894 & 1 & 1 & $\mathrm{D}$ & o \\
\hline 3 & Pebble & 10,336 & 1 & 1 & $\mathrm{D}$ & 1 \\
\hline 3 & Saunders & 8,500 & 1 & 1 & $\mathrm{E}$ & 1 \\
\hline 4 & Clarke's Islet & 5 & $\mathrm{o}$ & o & B & o \\
\hline 4 & The Fridays (2) & 21 & $\mathrm{O}$ & $\mathrm{O}$ & B & $*$ \\
\hline 4 & Grand Jason & 1,380 & 1 & $\mathrm{O}$ & $\mathrm{C}$ & o \\
\hline 4 & Steeple Jason & 790 & 1 & $\mathrm{O}$ & $\mathrm{C}$ & o \\
\hline 4 & Steeple Islet & 22 & o & $\mathrm{o}$ & A & * \\
\hline 5 & Flat Jason & 375 & o & o & A & * \\
\hline 5 & Dunbar & 225 & 1 & o & $\mathrm{C}$ & o \\
\hline 5 & Wreck I. (larger of 4 ) & 5 & $\mathrm{o}$ & o & B & * \\
\hline 5 & Sedge & 330 & 1 & 1 & $\mathrm{C}$ & * \\
\hline 6 & Gibraltar Rock & 20 & o & $\mathrm{o}$ & A & $*$ \\
\hline 6 & South Fur & 25 & o & o & A & * \\
\hline 6 & The Twins (S) & 15 & o & o & A & o \\
\hline 6 & The Twins (N) & 8 & o & o & A & o \\
\hline 7 & Low & 75 & 1 & o & B & o \\
\hline 7 & Elephant Jason & 260 & 1 & o & $\mathrm{C}$ & o \\
\hline 7 & North Fur & 75 & $\mathrm{o}$ & o & A & $*$ \\
\hline 8 & Gid's (King George Bay) & 30 & 1 & o & $\mathrm{B}$ & * \\
\hline 9 & Rabbit (KG Bay) & 178 & 1 & $\mathrm{o}$ & $\mathrm{D}$ & * \\
\hline 9 & Green (KG Bay) & 4 & $\mathrm{O}$ & $\mathrm{o}$ & $\mathrm{A}$ & * \\
\hline 9 & Hummock (KG Bay) & 303 & 1 & $\mathrm{O}$ & D & * \\
\hline 9 & Middle (KG Bay) & 155 & 1 & o & $\mathrm{D}$ & * \\
\hline 9 & 1st Passage & 750 & 1 & 1 & $\mathrm{D}$ & 1 \\
\hline 10 & 2nd Passage & 650 & 1 & $\mathrm{o}$ & $\mathrm{D}$ & * \\
\hline 10 & Split (S of West Pt I) & 220 & $\mathrm{O}$ & $\mathrm{O}$ & B & * \\
\hline 11 & Double (W/Spring Pt) & 9 & 1 & $\mathrm{o}$ & A & 1 \\
\hline 12 & Outer $(\mathrm{W} /$ Spring $\mathrm{Pt})$ & 20 & 1 & $\mathrm{O}$ & $\mathrm{A}$ & 1 \\
\hline 12 & Double (W/Spring Pt) & 2,363 & 1 & 1 & $\mathrm{D}$ & 1 \\
\hline 13 & Beaver & 4,856 & 1 & 1 & $\mathrm{D}$ & 1 \\
\hline 13 & Governor & 220 & 1 & $\mathrm{O}$ & $\mathrm{D}$ & 1 \\
\hline 14 & Bird & 120 & $\mathrm{o}$ & o & A & o \\
\hline 15 & Ten Shilling Bay (E and W) & 72 & 1 & o & A & 1 \\
\hline 15 & Is. 'Two' (E/Cross I.) & 3 & $\mathrm{o}$ & o & A & 1 \\
\hline 15 & Is. 'Four' (E/Cross I.) & 2 & $\mathrm{O}$ & $\mathrm{o}$ & A & 1 \\
\hline 15 & Is. 'Five' (E/Cross I.) & 1 & o & o & A & 1 \\
\hline 15 & Is. 'Six' (E/Cross I.) & 1 & * & o & A & 1 \\
\hline 15 & Cross & 65 & 1 & 1 & C & 1 \\
\hline 16 & Tussac (W/Big Arch) & 18 & 1 & $\mathrm{O}$ & A & 1 \\
\hline 16 & Big Arch & 200 & $*$ & o & A & 1 \\
\hline 16 & Natural Arch & 88 & $*$ & $\mathrm{O}$ & A & 1 \\
\hline 16 & Sand Bay (W/Big Arch) & 18 & o & o & A & 1 \\
\hline 17 & Emily (E/George I.) & 9 & 1 & o & A & o \\
\hline 17 & Tiny (E/George I.) & 6 & 1 & $\mathrm{O}$ & A & $\mathrm{O}$ \\
\hline 18 & Rum (S/Sea Lion I. & 7 & $\mathrm{o}$ & $\mathrm{o}$ & A & $\mathrm{O}$ \\
\hline 19 & Brandy (E/Sea Lion I.) & 25 & o & $\mathrm{O}$ & A & $\mathrm{O}$ \\
\hline 19 & Sea Lion Easterly & 85 & $\mathrm{o}$ & o & A & o \\
\hline 19 & Whisky (E/Sea Lion I.) & 13 & o & $\mathrm{o}$ & A & o \\
\hline 19 & Sea Lion I. & 905 & 1 & 1 & $\mathrm{C}$ & o \\
\hline 19 & Beauchêne & 170 & o & $\mathrm{o}$ & A & o \\
\hline 20 & Outer Triste (S) & 9 & 1 & $\mathrm{o}$ & B & 1 \\
\hline 20 & Outer Triste (N) & 18 & 1 & $\mathrm{O}$ & B & 1 \\
\hline 20 & Triste & 155 & 1 & 1 & $\mathrm{D}$ & 1 \\
\hline 21 & The Mot & 10 & o & $\mathrm{o}$ & A & $\mathrm{o}$ \\
\hline 21 & Motley & 330 & 1 & $\mathrm{O}$ & $\mathrm{C}$ & $\mathrm{O}$ \\
\hline 22 & Middle (Choiseul Sd.) & 150 & 1 & $\mathrm{o}$ & $\mathrm{C}$ & $\mathrm{O}$ \\
\hline 23 & Kidney (NE/Stanley) & 32 & $\mathrm{O}$ & $\mathrm{o}$ & A & $\mathrm{O}$ \\
\hline
\end{tabular}




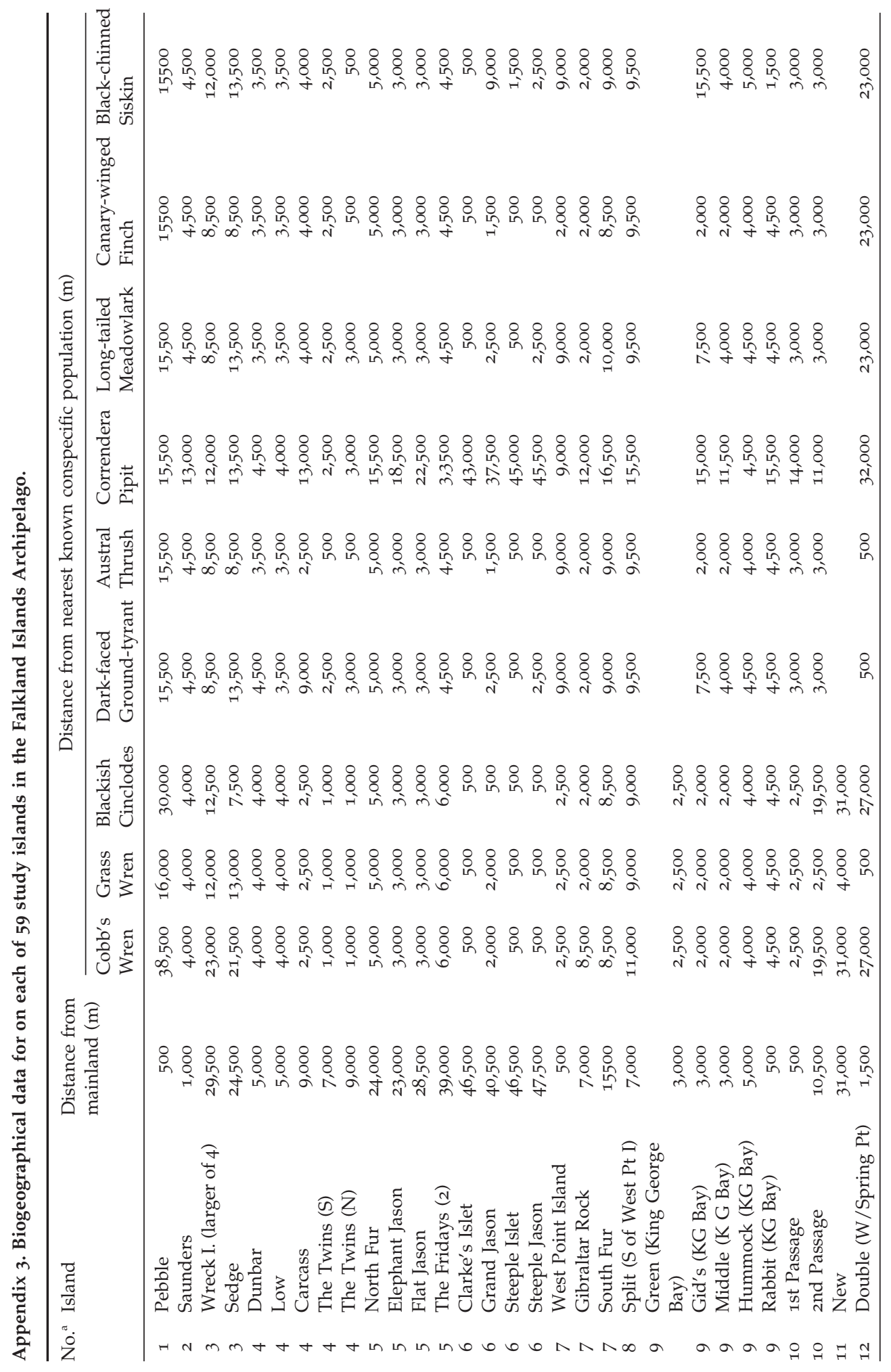




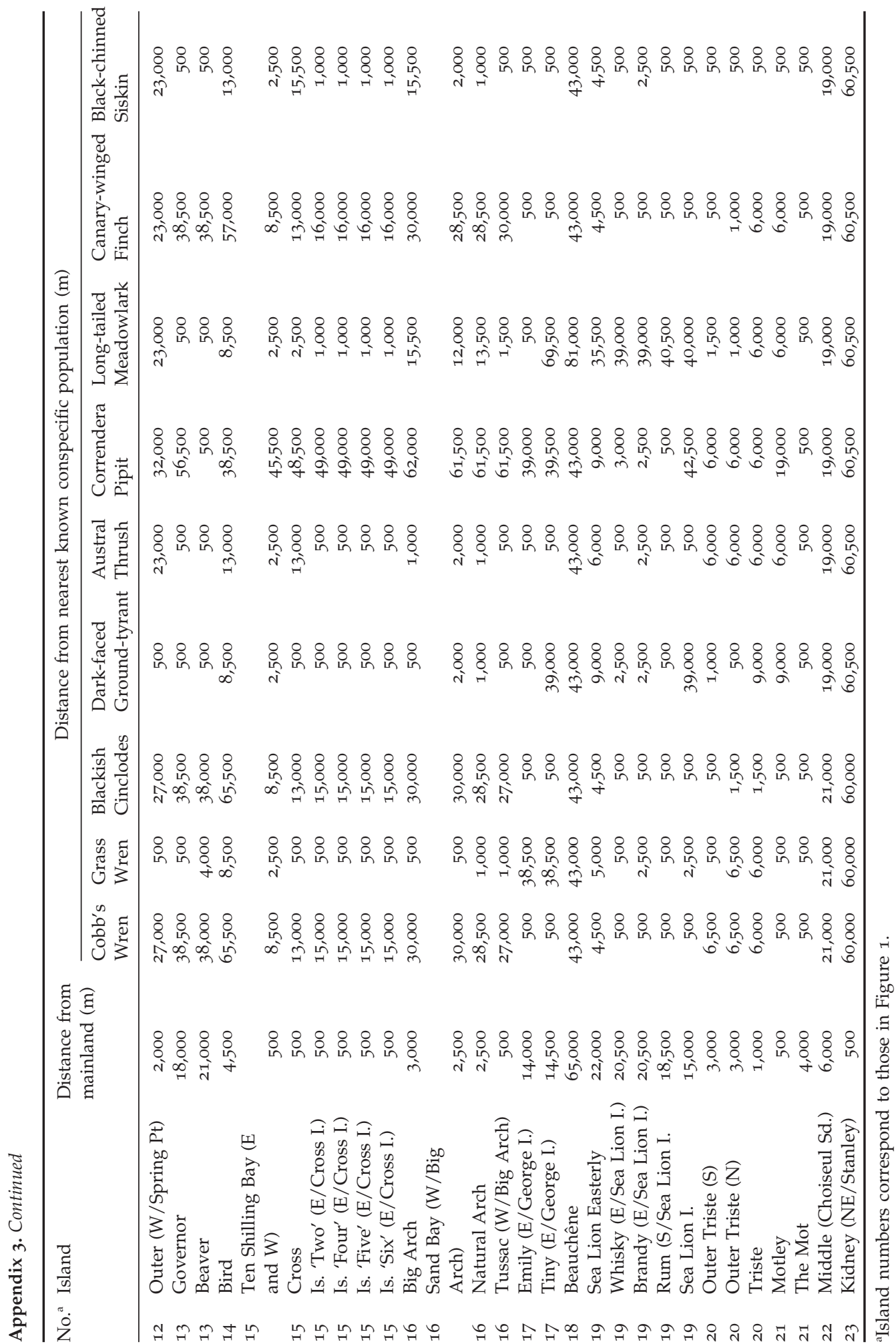




\section{References}

Atkinson, I. A. E. (1985) The spread of commensal species of Rattus to oceanic islands and their effects on island avifaunas. Pp. 35-81 in P. J. Moors, ed. Conservation of island birds. Cambridge, U.K.: International Council for Bird Preservation (Techn. Publ. 3).

Atkinson, I. A. E. (1989) Introduced animals and extinctions. Pp. 54-75 in D. Western and M. C. Pearl, eds. Conservation for the twenty-first century. New York: Oxford University Press.

BirdLife International (2000) Threatened birds of the world. Barcelona and Cambridge, U.K.: Lynx Edicions and BirdLife International.

Cawkell, E. M. and Hamilton, J.E. (1961) The birds of the Falkland Islands. Ibis 103a: 1-27.

Croxall, J. P., McInnes, S. J. and Prince, P. A. (1984) The status and conservation of seabirds at the Falkland Islands. Pp. 271-291 in J. P Croxall, P. G. H. Evans and R. W. Schreiber, eds. Status and conservation of the world's seabirds. Cambridge, UK: International Council for Bird Preservation (Techn. Publ. 2).

Diamond, J. (1975) Assembly of species communities. Pp. 342-444 in M. L. Cody and J. M. Diamond eds. Ecology and evolution of communities. Cambridge, MA: Harvard University Press.

Fleischer, R. C., McIntosh, C. E. and Tarr, C. L. (1998) Evolution on a volcanic conveyor belt: using phylogeographic reconstructions and K-Ar-based ages of the Hawaiian Islands to estimate molecular evolutionary rates. Mol. Ecol. 7: 533-545.

Grant, P. R. (1986) Ecology and evolution of Darwin's finches. Princeton, NJ: Princeton University Press.

Hanski, I. (1999) Metapopulation ecology. Oxford: Oxford University Press.

Johnson, T. H. and Stattersfield, A. J. (1990) A global review of island endemic birds. Ibis 132: $167-180$.

MacArthur, R. H. and Wilson, E. O. (1967) The theory of island biogeography. Princeton, NJ: Princeton University Press.

Moors, P. J. (ed.) (1985) Conservation of island birds. Cambridge, U.K.: International Council for Bird Preservation (Techn. Publ. 3).

Pettingill, O. S. (1974) Passerine birds of the Falkland Islands: their behaviour and ecology. Living Bird 12: 95-136.

Pimm, S. L., Jones, H. L. and Diamond, J. (1988) On the risk of extinction. Am. Nat. 132: 757-785.

Stattersfield, A. J., Crosby, M. J., Long, A. J. and Wege, D. C. (1998) Endemic Bird Areas of the world: priorities for biodiversity conservation. Cambridge, U.K.: BirdLife International.

Strange, I. J. (1992) Wildlife of the Falkland Islands and South Georgia. London: HarperCollins.

Strange, I. J., Parry, C. J., Parry, M. C. and Woods, R. W. (1988) Tussac grass in the Falklands. Port Stanley: Falkland Island Foundation Project Report.

Tilman, D., May, R. M., Lehman, C. L. and Nowak, M. A. (1994) Habitat destruction and the extinction debt. Nature 371: 65-66.

Whittaker, R. J. (1998) Island biogeography: ecology, evolution and conservation. Oxford: Oxford University Press.

Woods, R. W. (1970) The avian ecology of a tussock island in the Falkland Islands. Ibis 112: 15-24.

Woods, R. W. (1984) A census of breeding Falkland Islands passerine birds in tussac grass. Unpublished report.

Woods, R. W. (1986) How many islands in the Falkland Islands? Falkland Islands Foundation Newsletter 5: 8-9.

Woods, R. W. (1988) Guide to birds of the Falkland Islands. Oswestry, Shropshire, U.K.: Anthony Nelson.

Woods, R. W. (1993) Cobb's wren Troglodytes (aedon) cobbi of the Falkland Islands. Bull. Brit. Orn. Club. 113: 195-207. 
Woods, R. W. and Woods, A. (1997) Atlas of breeding birds of the Falkland Islands. Oswestry, Shropshire, U.K.: Anthony Nelson.

JAMES R. HALL and M. de L. BROOKE

Department of Zoology, University of Cambridge, Downing Street, Cambridge, U.K.

\section{ROBIN W. WOODS}

68 Aller Park Road, Newton Abbot, Devonshire, U.K.

\section{GEOFF M. HILTON ${ }^{1}$}

Royal Society for the Protection of Birds, The Lodge, Sandy, Bedfordshire, UK.

E-mail geoff.hilton@rspb.org.uk;

${ }^{1}$ Author for correspondence.

Received 13 June 2001; revision accepted 8 January 2002 
